\title{
The Effect of Product Quality, Brand Trust, Price and Sales Promotion on Purchase Decisions on Royal Residence Surabaya (Case Study in PT. Propnex Realti Visit)
}

\author{
Yuni Rahmawati ${ }^{1}$, Sengguruh Nilowardono ${ }^{2}$ \\ Narotama University Surabaya, Indonesia \\ rahmawati.yuni95@gmail.com
}

\begin{abstract}
This study aims to explore the decision to purchase Royal Residence Housing products in Surabaya. Exploration of Royal Residence Housing products is carried out using quantitative research methods.Data testing is done by questionnaires analyzed using statistical analysis such as validity and reliability tests and multiple linear regression analysis with the help of SPSS 21.0 for Windows. The results showed that the independent variable (product), product quality, brand trust, price and promotion simultaneously had an effect on the dependent variable, namely the purchase decision to produce conclusions, that is, accepted. This is evidenced by the significance value of 0.000 or less than 0.05 and the value of Fcount (61.441)> Ftable (2.71). There is a significant and not significant partial effect of the independent variable on the dependent variable. Through the results of calculations that have been done with a significant level of results of 0.000 is smaller than 0.05 .
\end{abstract}

Keywords: Product quality, Brand Trust, Price, and Sales Promotion

\section{INTRODUCTION}

\section{Background and Motive of Research}

The level of need to have a place to live (house) is currently increasing. In big cities, where population growth continues to increase plus the flow of urbanization that has never subsided, the need for housing has become one of the basic human needs which is very urgent.

A house besides its main function as a place of residence for its inhabitants, is also a benchmark for the existence of the owner's social status, in fact, people often buy a house because of economic purposes, namely as a place to live, also as a place to conduct business activities. In this case study the author discusses several factors or variables that influence the decision to buy a house at Royal Resindence Surabaya through the agent company PT. Propnex Realti Tunjungan. PT. Propnex Realti Tunjungan.

The Effect of Product Quality, Brand Trust, Price and Sales Promotion on Purchase Decisions on Royal Residence Surabaya (Case Study in PT. Propnex Realti Visit) 


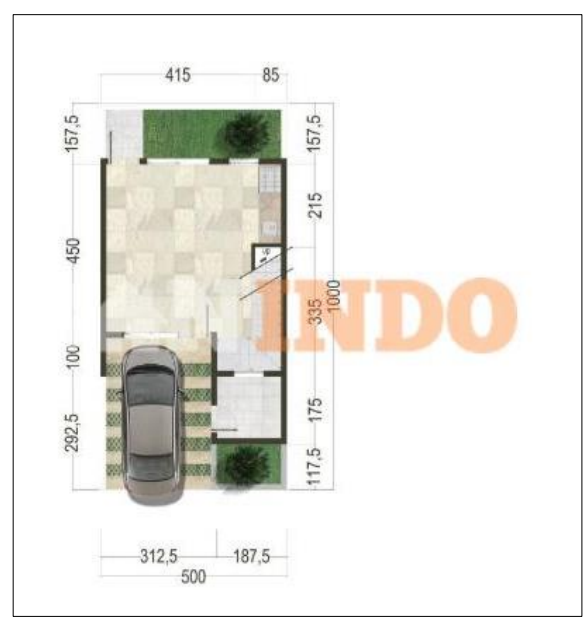

Figure 1. Siteplan Housing Royal Residence Surabaya 1st Floor

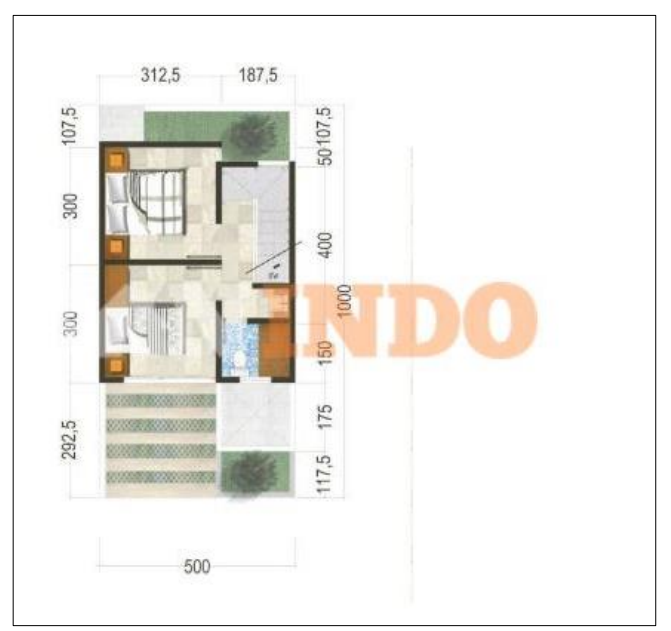

Figure 2. Siteplan Housing Royal Residence Surabaya Level 2

PT. Propnex Realti Tunjungan faces, problems at prices that are still considered too high by some consumers are considered to affect sales targets that are not as expected. According to Gitosudarmo (2000) price is the amount of money needed to obtain a number of goods along with certain services or a combination of both. Price is the second control factor that can be handled by sales or marketing management to understand the core point of decision making concerning pricing. Based on the price definition above, it can be concluded that the price is the amount of money that must be spent by consumers to get the product or service they buy to meet their needs and each variation has a price as well. 
Based on the background the problem that has been raised is

1. Are there significant influences, simultaneously, product quality variables, brand trust, prices and sales promotions on purchasing decisions at Royal Residence Suarabaya Housing.

2. Is there a significant, partially, variable in product quality on purchasing decisions at Royal Residence Surabaya Housing.

3. Is there a significant, partially, variable brand trust effect on purchasing decisions at Royal Residence Surabaya Housing.

4. Is there a significant, partially, variable price effect on purchasing decisions at Royal Residence Surabaya Housing.

5. Is there a significant influence, partially, on sales promotion variables on purchasing decisions at Royal Residence Surabaya Housing.

The purpose of this study was to analyze the quality of products, brand trust, prices and sales promotions against purchasing decisions at Royal Residence Surabaya Housing.

\section{LITERATURE REVIEW}

\section{Marketing}

The definition of marketing according to Stanton (2003) is a whole system that deals with business activities that aim to plan, determine prices, to promote, and distribute goods or services that will please both actual and potential buyers' needs.

\section{Product Quality}

According to Kotler and Armstrong (2003) product quality is the ability of a product to carry out all its functions, including durability, reliability, accuracy produced, ease of operation and repair, and other attributes that are valuable to the product as a whole.

\section{Brand Trust}

According to Lau and Lee in. Tjahyadi (2006) brand trust is defined as the customer's desire to rely on a brand with the risks faced because the brand's expectations will lead to positive results.

\section{Price}

According to Kotler and Armstrong (2008) the price is "a sum of money billed for a product or service, or the sum of all the values given by the customer to benefit from owning or using a product or service".

\section{Sales Promotion}

According to Tjiptono (2008), sales promotion is a form of direct persuasion through the use of various incentives that can be arranged to stimulate product purchases immediately or increase the amount of goods purchased by customers.

\section{RESEARCH METHODS}

\section{Research Structure}

Based on the objectives and relevant literature, this study proposes a research model of the effects of Product Quality, Brand Trust, Price and Sales Promotion, and the model is shown in Figure 3: 


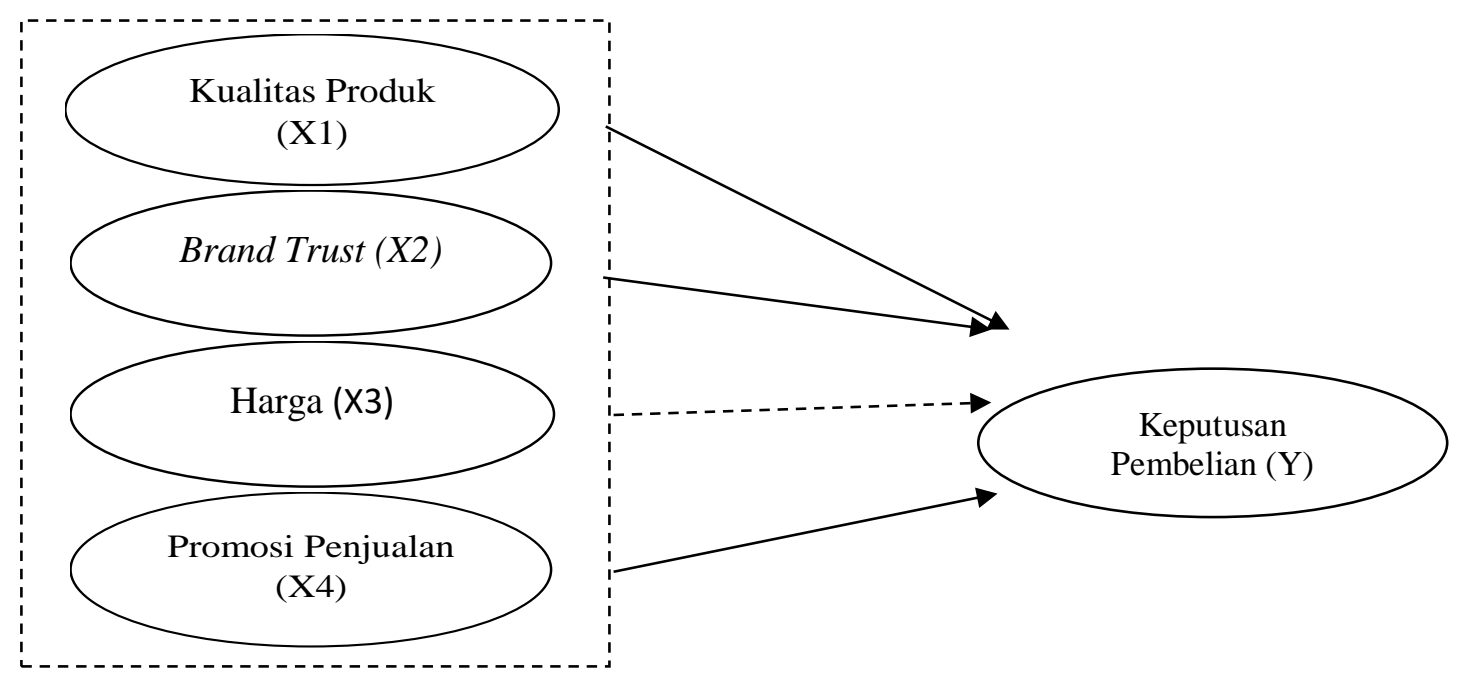

Fig. 3. Research Framework

\section{Research Hypotheses}

H1: Product Quality, Brand Trust, Price and Sales Promotion simultaneously have a significant effect on purchasing decisions at Royal Residence Surabaya Housing.

H2: Product Quality, Brand Trust, Price and Sales Promotion have a partial influence on purchasing decisions at Royal Residence Surabaya Housing.

H3: Which of the Product Quality, Brand Trust, Price and Sales Promotion has a dominant influence on purchasing decisions at Royal Residence Surabaya Housing.

\section{The type of research}

The type of research used in this research is the correlational quantitative method of descriptive research approach and verbal analysis.

\section{Population and Sampling}

The population in this study were all consumers of PT. Propnex Realty Tunjungan with a total sample of 100 people.

\section{Types, Sources and Data Collection Techniques}

The variable in this study used is the first independent variable (X1) is Product Quality, the second independent variable (X2) is Brand Trust, the third independent variable (X3) is Price, the fourth independent variable (X4) is the Sales Promotion and the dependent variable used in this study is a Purchasing Decision.

\section{Data Analysis Techniques}

The Effect of Product Quality, Brand Trust, Price and Sales Promotion on Purchase Decisions on Royal Residence Surabaya (Case Study in PT. Propnex Realti Visit) 
1. Test Validity and Reliability

2. Test of Classical Assumption

3. Multiple Linear Regression Test

$\mathrm{Y}=\mathrm{a}+\mathrm{b} 1 \mathrm{X} 1+\mathrm{b} 2 \mathrm{X} 2+\mathrm{b3} \mathrm{X3}+\mathrm{b} 4 \mathrm{X} 4+\mathrm{e}$

Where :

Y: Purchase Decision

a: Constants

b1, b2, b3, b4: Regression coefficients for variable X1

X1: Product Quality Variable

X2: Variable Brand Trust

X3: Price Variable

X4: Sales Promotion Variables

e: Error, variable interference

4. Hypothesis testing

a. $\quad$ Partial Test (T Test)

This test aims to examine whether the independent variables (product quality, brand trust, price, and sales promotion) on the dependent variable (purchase decision) have a partial or separate influence.

b. $\quad$ Test $\mathrm{F}$

The F test is used to determine the effect of the Royal Residence House Purchase process based on product quality, brand trust, price, and sales promotion), as a simultaneous purchasing decision process.

\section{RESULTS AND DISCUSSION}

\section{Demografi Customer}

Table 1. Characteristics Customers

\begin{tabular}{ccc}
\hline Gender & Total & Percent $(\%)$ \\
Man & 64 & 64.0 \\
Women & 36 & 36.0 \\
Total & 100 & 100.0 \\
\hline Age & Total & Percent $(\%)$ \\
\hline 20-25 year & 12 & 12.0 \\
26-30 year & 29 & 29.0 \\
31-35 year & 16 & 16.0 \\
36-40 year & 12 & 12.0 \\
41-45 year & 31 & 31.0 \\
\hline Total & 100 & 100.0 \\
\hline Work & Total & Percent $(\%)$ \\
\hline
\end{tabular}

The Effect of Product Quality, Brand Trust, Price and Sales Promotion on Purchase Decisions on Royal Residence Surabaya (Case Study in PT. Propnex Realti Visit) 


\begin{tabular}{ccc}
\hline Housewife & 9 & 9.0 \\
Private employees & 27 & 27.0 \\
Civil servants & 14 & 14.0 \\
Entrepreneur & 43 & 43.0 \\
Student & 7 & 7.0 \\
\hline Total & 100 & 100.0 \\
\hline
\end{tabular}

Test Validity and Reliability

Based on the validity of all statement items has a correlation value that is greater than $r$ table (greater than 0.1966), so that all items submitted questions are declared valid and feasible for analysis. Based on the reliability of all variable values, both the independent variable and the dependent variable all meet the requirements, meaning that all items are declared reliable or reliable.

Multiple Analysis Test Results

Table 2. Results of Multiple Regression Analysis Test

\begin{tabular}{llccc}
\hline \multicolumn{1}{c}{ Variabel } & Koefisien Regresi & Thitung & Sig. \\
\hline Konstanta & & & -0.403 & 0.688 \\
\hline Product Quality (X1) & & 0.362 & 4.779 & 0.000 \\
\hline Brand Trust (X2) & & -0.14 & -0.130 & 0.897 \\
\hline Price (X3) & & -0.555 & 7.335 & 0.000 \\
\hline Sales Promotion (X4) & & 0.026 & 0.230 & 0.819 \\
\hline Fhitung & $\mathbf{: 6 1 . 4 4 1}$ & & & \\
Signifikan & $\mathbf{: 0 . 0 0 0}$ & & & \\
$\mathbf{R}$ & $\mathbf{: 0 . 8 4 9}$ & & & \\
$\mathbf{R}^{2}$ & $\mathbf{0 . 7 2 1}$ & & & \\
Adjusted Rsquare & $\mathbf{: 0 . 7 0 9}$ & & & \\
\hline
\end{tabular}

By entering the values obtained from the SPSS calculations above, multiple regression equations can be obtained, that is:

$$
\begin{aligned}
& \hat{Y}=a+b_{x 1}+b_{x 2}+b_{x 3}+b_{x 4} \\
& \hat{Y}=0.325+0.362_{x 1}+-0.14_{x 2}+-0.555_{x 3}+0.026_{x 4}
\end{aligned}
$$

Description:

1. The constanta number of -0.403 states that if there is no variable in product quality, brand trust, price, and sales promotion, then the decision to purchase Royal Residence Housing products is 0.403 units

The Effect of Product Quality, Brand Trust, Price and Sales Promotion on Purchase Decisions on Royal Residence Surabaya (Case Study in PT. Propnex Realti Visit) 
2. Regression coefficient 0.362 (X1), states that each addition of 1 (one) unit will increase the purchasing decision 0,362 units.

3. Regression coefficient -0.14 (X2), states that each addition of 1 (one) unit will increase the purchasing decision of -0.14 units.

4. Regression coefficient of 0.555 (X3), states that each addition of one 1 (one) unit will increase the purchasing decision by 0.555 units

5. Regression coefficient of 0.026 (X4), states that each addition of one 1 (one) to units will increase the purchasing decision by 0.026

\section{T Test}

This shows that product quality, brand trust, price and purchase promotion variables have a significant and not significant effect on the purchasing decisions of Royal Residence Housing. Based on respondents' answers about product quality, brand trust, price, and sales promotion it turns out that the price variable is the most dominant variable that influences the purchase decision of Royal Residence Housing. It also has $t$ count $=4.779$ (for product quality variables) $>\mathrm{t}$ count $=-130$ (for brand trust variables $<\mathrm{t}$ count $=7.335$ (for price variables) and $\mathrm{t}$ count $=0.230$ (for sales promotion variables). product quality, brand trust, price and sales promotion partially influence the purchase decision of Royal Residence Housing.

\section{F Test}

Thus conclusions can be drawn, which is obtained $\mathrm{F}$ count is 61.441 with a significant level of 0.000 . While the value of Ftable $=2.71$ by looking at table $\mathrm{F}$ and how to read the table from df (degree of freedom) Regression with nominal 3 and df (degree of freedom) Residual with nominal 86. Because probability (0.000) is much smaller than 0.005 then the regression model can be used to predict purchasing decisions. In accordance with the decision-making criteria of the F test, which is the Fcount value (61.441)> Ftable (2.71), the independent variables jointly influence the dependent variable, or product quality, brand trust, price and sales promotion are jointly influential significant to the Royal Residence Housing purchase decision. This means that the hypothesis states that simultaneously the variable quality of the product, brand trust, price and sales promotion affect the purchase decision of the Royal Residence Housing can be accepted.

\section{Discussion}

Product quality is considered an important thing in determining the choice of a product by consumers. Products offered must be a product that is truly well tested in terms of quality. Because for consumers who are prioritized is the quality of the product itself. Consumers will prefer and choose products that have better quality when compared to other similar products that can meet their needs and desires. Quality determination is one way to win competition in the market, because quality is one way of placing a product in the minds of consumers.

According to Kotler and Armstrong (2003) product quality is the ability of a product to carry out all its functions, including durability, reliability, accuracy produced, ease of operation and repair, and other attributes that are valuable to the product as a whole. Brand Trust is a perception of reliability from the consumer's point of view based on experience, or more on the sequence of transactions or interactions characterized by the fulfillment of expectations for product performance and satisfaction (Ferinnadewi, 2008). Trust is built up because of the hope that other parties will act according to the needs and desires of consumers.

Brand trust is the willingness of the average consumer todepends on the ability of a brand to carry out all its uses or functions (Chaudhuri and Holbrook, 2001). Instruments used to measure brand trust are based on instruments developed by Chaudhuri \& Holbrook (2001).

The Effect of Product Quality, Brand Trust, Price and Sales Promotion on Purchase Decisions on Royal

Residence Surabaya (Case Study in PT. Propnex Realti Visit)

Yuni Rahmawati, Sengguruh Nilowardono 
Price is a unit of value given to a commodity as information on the counterparty of the producer / owner of the commodity. In economic theory, it is stated that the price of an goods or service whose market is competitive, the high and low prices are determined by market demand and supply. With the right pricing, consumers will not feel burdened and will not result in a decrease in the purchasing power of consumers, which in turn will achieve the company's goals of achieving sales as much as possible so as to create profits for the company.

According to Kotler and Armstrong (2008) the price is "a sum of money billed for a product or service, or the sum of all the values given by the customer to benefit from owning or using a product or service".

Sales promotion is one form of marketing communication that aims to attract new consumers, influence consumers to try new products, encourage more consumers, attack competitors' promotional activities, increase purchases without plans or seek closer cooperation with retailers, as a whole. sales promotion techniques only affect the short term. According to Tjiptono (2008), the definition of sales promotion is a form of direct persuasion through the use of various incentives that can be arranged to stimulate product purchases immediately or increase the amount of goods purchased by customers. Conclusions and Suggestions.

\section{CONCLUSIONS AND SUGGESTIONS}

\section{Conclusions}

Based on the results of data analysis obtained from the calculated value on the product quality variable is 4.779 while the $t$ table is 1.988 then $t$ count $>t$ table $4.779>1.988$ with a significant level of 0.000 . Because $t$ count $>t$ table then. This indicates that product quality $(\mathrm{X} 1)$ partially has a significant effect on consumer loyalty (Y). So that the influence of product quality on purchasing decisions shows that the high quality of products contributes significantly to the purchase decision of Royal Residence Surabaya Housing.

Based on the results of the analysis the data obtained from the t-count value on the brand trust variable is -130 while the $\mathrm{t}$ table is $1.988, \mathrm{t}$ count $<\mathrm{t}$ table $-13<1.988$ with a significant level of 0.897 . Because $t$ count $<\mathrm{t}$ table, this indicates that brand trust (X2) partially has no significant effect on purchasing decisions (Y). So that the influence of brand trust on purchasing decisions shows that the high brand trust contributes significantly to the purchase decision of Royal Residence Surabaya Housing.

Based on the results of analysis of data obtained from the results of the F test (simultaneous influence test). The calculated F-value is $61.441>\mathrm{F}$ table 3.09 with a significant level of 0.000 . Because $\mathrm{F}$ count $>\mathrm{F}$ table then. This indicates that product quality $(\mathrm{X} 1)$, brand trust $(\mathrm{X} 2)$, price $(\mathrm{X} 3)$, and sales promotion (X4) together or simultaneously have a significant effect on purchasing decisions (Y). So that the influence of product quality, brand trust, price, and sales promotion together or simultaneously have a significant effect on purchasing decisions, indicating that high product quality, brand trust, price, and sales promotion together will make a real contribution to purchasing decisions Royal residence in Surabaya.

\section{Advice}

Based on the analysis of the research stated earlier, the following suggestions can be taken:

1. For PT. Propnex Realti Tunjungan: To further increase its brand trust to the wider community, so that later prospective customers will be interested and then trust the company. After that consumers will increase their purchasing decisions.

2. For future researchers: The results of this study should be used as a basis for deepening the study of marketing management. Which is adapted to new theories in the future. And it is recommended to look for different locations so that you can compare the results of existing research with research that will be implemented.

The Effect of Product Quality, Brand Trust, Price and Sales Promotion on Purchase Decisions on Royal

Residence Surabaya (Case Study in PT. Propnex Realti Visit)

Yuni Rahmawati, Sengguruh Nilowardono 


\section{REFERENCES}

Boyd, Harper, W, et al. (2000). Marketing Management. Jakarta: Erlangga.

Ferdinand, (2002). Marketing Management. First edition. Volume I. Jakarta: Erlangga

Frontline (2001), The Merchants of Cool: Report on Creators \& Marketers of Popular Culture for Youth. (http://www.pbs.org/wgbh/pages/frontline/shows/Cool), accessed 30 April 2017

Ghirvu, A. (2012). ADVERTISING IN THE GAME: ADVANTAGES AND LIMITATIONS FOR ADS. USV Annals of Economics and Public Administration. Volume 12, Issue 1 (15)

Gitosudarmo, I. (2000). Marketing Management. Second Edition of the Sixth Print. Yogyakarta: BPFE.

Ghozali, Imam. (2006). Econometrics. Semarang: UNDIP Publishing Agency

Ghozali, Imam. (2002). Application of Multivariate Analysis with the SPSS Program. Semarang: Diponegoro University Publishing Agency Semarang.

Dirty, Michelle. L. (2010). Advergamers and Effects of game-product congruity. Computers in Human Behavior 26 (2010) 1259-1265

Hair, Joseph F et al. 2006. Multivariate Data Analysis. 6 ed. NJ: Person Prestice Hall: Upper Saddle River.

Huang, J, H; Yang, T, K. (2012). Effectiveness of In-Game Advertising: Impact of Types of Ads in Games and the Relevance of Games / Ads. International Journal of Electronic Business Management. Vol. 10, No. 1, p. 61-72.

Kotler, P, Keller, K (2006). Marketing Management. Volume 2 Issue 12.

Kotler, P. (2008). Marketing Management. Jakarta: Erlangga

Kuncoro, Mudrajad. (2013). Research Methods for Business \& Economics. Fourth Edition. Jakarta: Erlangga.

Kusumasondjaja, S. (2016). Consumer Response to Mobile Advergames: Intrusiveness and Irritation. Journal of Technology Management, 15 (3), 2016,206-223

Lewis, Ben and Lance Porter (2010), "The Effects of In-Game Ads: Checking Players' Perceptions of Conformity to Advertising Schemes in Role-Each Online Role Playing Games," Interactive Advertising Journal, 10 (2), 46-60

Lidyawatie, (2008). Marketing and Service Marketing Management. Bandung: Alfabeta.

Maulana, A. (2016). Indonesian Smartphone Internet Users Grow Blessing. (http://www.cnnindonesia.com/teknologi/20160222155236-213-112610/pengguna-internetindonesia-tumbuh-berkat-smartphone/), access 26 April 2016

McCharthy, E. Jerome. (2002). Marketing Basics. Jakarta: Erlangga

Millward, S. (2014). Indonesia is projected to exceed 100 million smartphone users in 2018, Four in the world. (https://id.techinasia.com/jumlah-pengguna-smartphone-di-indonesia-2018), accessed May 14,2017

Muzellec, L., Kanitz, C., Lynn, T. (2013). Want coffee with friends at 'Central Perk'?

Sudaryono, (2010). Application of Analysis (Path Analysis) Based on the Order of Variable Placement in Research. Journal of the Minister of Education and Culture. 2010 - 2016. (http://jurnaldikbud.kemdikbud.go.id/index.php/jpnk/article/viewFile/36/33) accessed May 17, 2017

Sugiyono. (2008). Business Research Methods. Eleventh Mold. Bandung: Alfabeta

Sunyoto. (2012). Basic Concepts of Marketing Research and Consumer Behavior. First print. Yogyakarta: CAPS

Swastha, Basu. (2002) Modern Marketing Management. Yogyakarta: Freedom.

The Effect of Product Quality, Brand Trust, Price and Sales Promotion on Purchase Decisions on Royal

Residence Surabaya (Case Study in PT. Propnex Realti Visit)

Yuni Rahmawati, Sengguruh Nilowardono 
Thamrin. (2003). Marketing strategy. Yogyakarta: Andi Publisher

Tina Winkler and Kathy Bucker. (2006). GAMER DELAYS TO BRAND MESSAGE RIGHT IN ADVERTISING: ATTITUDE TO PRODUCT PLACEMENT. Interactive Advertising Journal, Vol 7 No. 1

Tjiptono, F. (2012). Strategic Marketing. Second edition. Yogyakarta: Andi Offset

Verolien and Patrick De Pelsmacker. (2010). Impact of Brand Excellence and Game Repeat on Brand Response. Journal of Advertising, vol. 39, no. 1 